University at Buffalo School of Law

Digital Commons @ University at Buffalo School of Law

Journal Articles

Faculty Scholarship

2012

\title{
The Value of Valor: Money, Medals and Military Labor
}

Mateo Taussig-Rubbo

University at Buffalo School of Law

Follow this and additional works at: https://digitalcommons.law.buffalo.edu/journal_articles

Part of the First Amendment Commons

\section{Recommended Citation}

Mateo Taussig-Rubbo, The Value of Valor: Money, Medals and Military Labor, 88 N.D. L. Rev. 283 (2012). Available at: https://digitalcommons.law.buffalo.edu/journal_articles/143

(C) 2012 North Dakota Law Review.

C. ${ }_{\text {COPYRIGHT }}^{\text {N }}$

This Article is brought to you for free and open access by the Faculty Scholarship at Digital Commons @ University at Buffalo School of Law. It has been accepted for inclusion in Journal Articles by an authorized administrator of Digital Commons @ University at Buffalo School of Law. For more information, please contact lawscholar@buffalo.edu. 


\title{
THE VALUE OF VALOR: MONEY, MEDALS, AND MILITARY LABOR
}

\author{
Mateo TAussig-RuBbo*
}

\begin{abstract}
The United States Supreme Court recently overturned the Stolen Valor Act on the ground that the law's blanket prohibition on falsely claiming to have received a military medal or decoration violated the First Amendment right to free speech. This Article uses the controversy provoked by the law to explore the implications of offering compensation for military service in the form of medals, in addition to money. How are these two, medals and money, related? Should we think of both as government issued, conventional forms of value? Querying the distinctions between money and medals, and the ways in which the boundaries around medals are drawn and policed, offers a means of considering the forms of value that underlie compensation for the work of those who fight in the name of the nation. In an era where value is increasingly assessed in monetary terms, what might medals tell us about the resistance of certain forms of value to such conversion? Furthermore, understanding the relation between medals and money is of vital importance because the government's increased use of private military contractors constitutes a retrenchment from a workforce that is paid in both forms of value - honor and money - to one that is paid in money alone.
\end{abstract}

* Associate Professor of Law, SUNY-Buffalo. This Article was presented at McGill Law School's Legal Theory Workshop and at the Schell Center for International Human Rights, Yale Law School. I am grateful to the participants at those events and to Mark Antaki, Hugo Cyr, Mary Dudziak, Eugene Fidell, Owen Fiss, Paul Kahn, Paul Linden-Retek, Daniel Markovits, Kiel Brennan-Marquez, Sam Moyn, Jonathan Sheehan, and Amiel Melnick for their comments. 


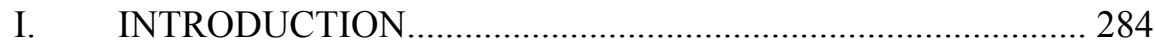

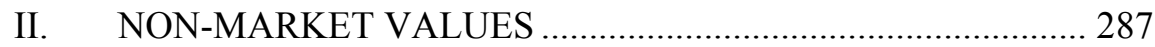

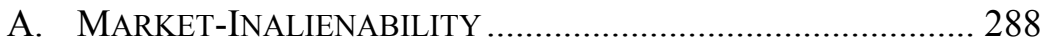

B. TRANSCENDENCE AND THE SACRED.................................... 290

C. ECONOMIC THEOLOGY ........................................................ 292

III. WEARING MONEY: THE VALUE OF

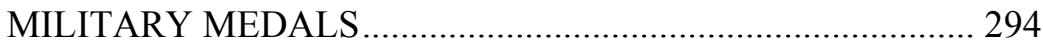

IV. THE MEDAL SYSTEM IN CONTEXT …………………........ 298

A. THE BUREAUSTOCRACY .................................................. 300

B. Giving Oneself: The ENLiSTMENT CONTRACT ................ 303

V. EXPORTING MEDALS TO THE CIVILIAN WORLD AND THE STOLEN VALOR ACT …............................................... 305

A. Medals IN THE CIVILIAN WORLD........................................ 306

B. "VALUE BegetS VALUE" ..................................................... 308

C. THE AlvareZ DeCISION .................................................... 312

VI. PRIVATE CONTRACTORS: FROM MEDALS TO MONEY …................................................... 315

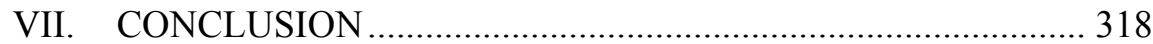

\section{INTRODUCTION}

The official website dedicated to the Purple Heart, a medal awarded to members of the armed forces wounded in action, recounts that the medal was originally created by General George Washington. ${ }^{1}$ Ordered by the Continental Congress to stop giving commissions and promotions, since the Congress could not afford the extra pay these entailed, Washington drew up orders for a Badge of Military Merit made of purple cloth. ${ }^{2}$ In 1782, he directed that "whenever any singularly meritorious action is performed, the author of it shall be permitted to wear on his facings, over his left breast, the

1. Ray Raymond, The Badge of Military Merit, MiL. ORD. OF THE PuRPLE HEART, http://www.purpleheart.org/Downloads/Raymond\%20Badge\%20of\%20Merit.pdf (last visited Mar. 30, 2012); see also U.S. DEP'T OF ARMY, REG. 600-8-22, PERSONNEL-GENERAL, MilitARY AWARDS para. 2-8 (11 Dec. 2006) [hereinafter AR 600-8-22].

2. $I d$. 
figure of a heart in purple cloth, or silk, edged with narrow lace or binding." 3

This origin story has been recounted numerous times of late, as the United States Supreme Court considered, and ultimately struck down, ${ }^{4}$ the Stolen Valor Act of $2005^{5}$ - a law that prohibited the false claim to have received a medal or decoration. ${ }^{6}$ Washington's story was referenced to illustrate how the current medal system can be traced to the earliest days of the Republic. ${ }^{7}$ It was also cited because, in his orders, Washington wrote that those who wore one of his badges without permission should be punished, thus supporting the imposition of penalties upon those who, in our own day, "steal" valor. ${ }^{8}$

But what is most intriguing about the story is not mentioned in the court proceedings: the way in which medals and money relate to one another as forms of compensation. ${ }^{9}$ In the story, the General gave cloth because he could not give money. This may seem unrelated to the legal dispute, since the issue in United States v. Alvarez ${ }^{10}$ was whether a free speech right existed to speak falsely about having received a medal.11 Yet, the prohibition on false statements is embedded within a broad separation of honor and medals from money and market circulation. It is a criminal offense to wear, purchase, sell, or barter military decorations or medals "without authorization," and they cannot be given in "exchange for

3. Id.; see also History of the Medal, DePT. OF CAL. Mil. ORD. OF THE PuRPLE HeART, http://calpurpleheart.org/History_of_the_Medal htm (last visited Jan. 7, 2013).

4. United States v. Alvarez, 132 S. Ct. 2537, 2548 (2012).

5. 18 U.S.C. $§ 704$ (b) (2006) ("Whoever falsely represents himself or herself, verbally or in writing, to have been awarded any decoration or medal authorized by Congress for the Armed Forces of the United States... shall be fined under this title, imprisoned not more than six months, or both.").

6. $I d$.

7. Alvarez, $132 \mathrm{~S}$. Ct. at 2548 (Kennedy, J., plurality opinion); Id. at 2557-58 (Alito, J., dissenting); see also Petition for Writ of Certiorari at 3, United States v. Alvarez, 132 S. Ct. 2537 (2012) (No. 11-210), 2011 WL 3645396 ("The government's tradition of awarding military honors in order to recognize acts of valor in service to the Nation dates back to the Revolutionary War. In 1782, General George Washington ordered the creation of several decorations recognizing military service and valor ....").

8. Brief for the American Legion as Amicus Curiae Supporting Petitioner at 4, United States v. Alvarez, 132 S. Ct. 2537 (2012) (No. 11-210), 2011 WL 6210435 ("None other than George Washington warned: 'Should any who are not entitled to the honors, have the insolence to assume the badges of them, they shall be severely punished."' (citations omitted)).

9. As I discuss below, some groups do discuss the medal system as a kind of "currency" unto itself in order to explain the harm done by "counterfeiters." See infra Part VI.A; see also Brief for the Legion of Valor of the United States \& Criminal Justice Legal Foundation as Amicus Curiae Supporting Petitioner at 4, United States v. Alvarez, 132 S. Ct. 2537 (2012) (No. 11-210), 2011 WL 6210434.

10. 132 S. Ct. 2537 (2012).

11. Alvarez, 132 S. Ct. at 2551. 
anything of value." 12 The prohibition on speech is but part of an endeavor to create and protect a class of honored persons within the society at large persons described by the Congressional Medal of Honor Foundation as "ambassadors," bringing a message of patriotism and sacrifice to America, each one a "national treasure."13 Valor and sacrifice are often construed by the Army (for convenience, this Article focuses on this part of the military) as exceeding legal duty and what money can buy. It seems that the honor bestowed through the medal is not commensurable with market value indeed, honor is often defined against money. However, this Article will suggest the relationship between money and medals is not so clearly defined.

The dispute around the Stolen Valor Act presents an opportunity to reflect upon the relation between market and non-market conceptions of "value" - a term deployed here in a capacious and flexible sense. ${ }^{4}$ Both medals and money are issued by the government; both are conventional forms of value. Are these simply two variations on a single idea of currency, or are they radically opposed forms of value?

First, this Article examines theoretical efforts to conceptualize forms of value other than as understood in the context of markets and money. 15 Second, it probes the Purple Heart origin story and discerns two ways in which recognition in non-monetary form relates to money compensation. ${ }^{16}$ In one, medals operate as a substitute; in another, they mark an incommensurable, different order of value, a debt that cannot be paid. These two conceptions - substitution and incommensurability - generate a tension that is not resolved, either in Washington's story or in our current configuration. Third, the Article situates the medal system in relation to some of the central features of our current military order and describes how in the Army there seems to be a well-established social currency of medals, a hierarchical system of valuation and reward that - while intersecting with money, is independent of it. 17 Fourth, in light of the legal, cultural, and economic separation of the military order from civilian life, this Article examines efforts to police and preserve the separate status of military honorific value in the civilian world, 18 including the Stolen Valor Act,

12. 18 U.S.C. $\S 704(a)$ (2006).

13. Brief for the Congressional Medal of Honor Foundation as Amicus Curiae Supporting Petitioner 3-4, United States v. Alvarez, 132 S. Ct. 2537 (2012) (No. 11-210), 2011 WL 6179422.

14. See David Graeber, Toward an Anthropological Theory of VAlue: the False COIN OF OUR DREAMS 33 (2001).

15. See infra Part II.

16. See infra Part III.

17. See infra Part IV.

18. See infra Part V. 
which seeks to preserve "the reputation and meaning of military decorations and medals." 19 Finally, this Article draws upon the discussion of medals and money to assess the increased reliance on private military contractors. 20 The line between medals and money is deeply related to the line between soldier and contractor, all the more so when we deem the latter a "mercenary." While the soldier receives both forms of compensation, the contractor typically only receives money, and is thus excluded from most military awards. ${ }^{21}$ This shift seems especially worthy of consideration as contractor fatalities surpassed those of soldiers. 22

The main issue is how the policy of valuing valor and creating a medal currency intersects with the distribution of power and authority in our political order. Does valuing military valor through medals empower some actors (those in the military, or medal wearers, and those who bestow the honors) over others (the civilian population)? Alternately, might the hierarchy of honor be a way for civilians to claim that their debt has been recognized and perhaps even discharged? Paying in medals implies that the money offered the soldier was not enough - that pay is never enough, and that what the medal signifies is an ongoing obligation. This may be appropriate, but it may also be troubling. Why not pay what is owed, now? The medal system constitutes a domain of value distinct from monetary value. As we will discover, this distinction is a fragile achievement.

\section{NON-MARKET VALUES}

This section critically engages legal theorists Margaret Jane Radin and Paul Kahn, both concerned with sites of value not reducible to markets and money - Radin with personhood, and Kahn with sovereignty. Finding that both Radin and Kahn tend toward a dichotomous framework that inadvertently reaffirms an opposition between market and non-market ideas of value, this section turns to anthropologists David Graeber and Keith Hart to develop a perspective from which the oppositions - between market and

19. Stolen Valor Act of 2005, Pub. L. No. 109-437, § 2, 120 Stat. 3266, 3266 (2006).

20. See Comm'n on WARtime Contracting in IraQ \& AFG., Transforming Wartime

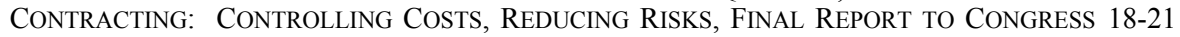
(2011) [hereinafter COMM'N ON WARTIME CONTRACTING].

21. AR 600-8-22, supra note 1, at 53-54 tbl. 3-4. The regulation lists which medals may be given to United States or foreign civilians. Id.; see also CROMWELL GIBBONS, MiLITARY DECORATIONS AND CAMPAign SERVICE BARS OF THE UNITED STATES 66 (1943).

22. Steven L. Schooner \& Collin D. Swan, Dead Contractors: The Un-Examined Effect of Surrogates on the Public's Casualty Sensitivity, 40 J. NAT'L L. SECURITY \& POL'Y 11, 13 (2012); T. Christian Miller, This Year, Contractor Deaths Exceed Military Ones in Iraq and Afghanistan, ProPubliCA (Sept. 23, 2010), http://www.propublica.org/article/this-year-contractor-deathsexceed-military-ones-in-iraq-and-afgh-100923. 
state, market and personhood, money and medals - can be seen as mutually constituting.

\section{A. MARKET-INALIENABILITY}

Margaret Jane Radin has explored a concept of "market-inalienability" by outlining what she describes as "property for personhood." 23 This is a form of property deeply bound together with personal identity, as contrasted with that which is fungible and held instrumentally. ${ }^{24}$ Using the example of wedding rings, Radin urges that some forms of property, based on the degree to which they are expressive of personhood, should receive greater protection than other forms of property. 25 A wedding ring belongs to its wearer in a different way than other property might (perhaps the soldier's medal bears some resemblance). In linking property and personhood, Radin describes an important category of things that resist marketization. But the "personal" is not the only field that resists marketization, and money is not only an expression of market value.

In addition to the personal property Radin describes, we can identify forms of non-market value that are not personal, such as sovereign territory, or sacred or religious property. 26 There are ways in which personhood is developed and relates to non-market value that emerge not as an expression of an internal personal identity, but by looking beyond the self and finding value in objects precisely because they are not of the self. 27 Along these lines, property scholars have extended Radin's conception of personhood to the collective level - peoplehood - in writing, for example, about indigenous peoples. Kristen Carpenter, Sonia Katyal, and Angela Riley urge that "Radin's account of personhood captures precisely the meaning that cultural property may carry for indigenous people: that some properties are so constitutive of one's identity that they demand treatment that transcends - and surpasses - that of an ordinary market transaction." 28 This conception expands the frame on what is considered property and what kind of entity holds it. But it is not only relevant to indigenous communities. Indeed, in our society, sites, objects, and documents are

23. Margaret Jane Radin, Property and Personhood, 34 StAN. L. REV. 957, 960 (1982) ("I shall call these theoretical opposites - property that is bound up with a person and property that is held purely instrumentally - personal property and fungible property respectively.").

24. Id. at $959-60$.

25. See id. at 959-60, 1005.

26. As Radin has also noted. MARgaret JANE RADIN, REINTERPRETING Property 13 (1993).

27. For a similar critique, see Jeffrey Douglas Jones, Property and Personhood Revisited, 1 WAKE FOREST J. L. \& POL'Y 93, 127-28 (2011).

28. Kristen A. Carpenter et al., In Defense of Property, 118 YALE L.J. 1022, 1048 (2009). 
similarly constitutive of collective identity. 29 The sale of medals is prohibited under the same part of the United States Code where we find the Stolen Valor Act. We could see medals as a kind of personal property in Radin's terms, which perhaps captures how some veterans relate to their medals. But medals express other kinds of non-market value as well, such as the public, collective, or sovereign values the medal instantiates.

A second elaboration of Radin's framework concerns an understanding of money as an object of the market. We should recall that money as we know it is as much a creation of the state as the market, and in some of its forms it bears the sovereign's inalienable stamp on its face. ${ }^{30}$ Keith Hart draws attention to this in his seminal article on money:

Look at a coin in your pocket. On the one side is 'heads' - the symbol of the political authority which minted the coin; on the other side is 'tails' - the precise specification of the amount the coin is worth as payment in exchange. One side reminds us that states underwrite currencies and the money is originally a relation between persons in society, a token perhaps. The other reveals the coin as a thing, capable of entering into definite relations with other things ....31

Hart contrasts a "commodity" theory of money - which usually contends that money should be tied to specie - to various "token" theories, which see money as a product of the state. 32 In Hart's terms, Radin may see only one side of the coin - the market. To interpret exchange for money as being only about the market leaves unexamined the manner in which the sovereign creates money, or at least one side of the coin. 33 The central point is that the examination of different forms of value should not accept a simple theory of money. The dichotomies that underpin Radin's core distinction between the fungible and the personal - between objects that

29. See Mateo Taussig-Rubbo, Sacred Property: Searching for Value in the Rubble of 9/11, in AFTER SECULAR LAW 322, 322 (Winnifred Fallers Sullivan et al. eds., 2011).

30. Keith Hart, Heads or Tails? Two Sides of the Coin, 21 MAN 637, 638 (1986); see also Bill Maurer, The Anthropology of Money, 35 ANN. REV. ANTHROPOLOGY 15, 27 (2006).

31. Hart, supra note 30 , at 638 .

32. Id. at 645-46 ("There are thus three types of theory opposed to the classical orthodoxy which regards money solely as a commodity, subject to the laws of competitive markets. These are all token theories which insist that money is a symbol for something intangible, an aspect of human agency, not just a thing like a lump of coal. Money as trust locates value in the morality of civil society; its fulcrum is the management of credit and debt in human relations. ... Money as the expression of state policy emphasizes the role of law and government intervention.... The populist theory of money stresses the accumulated institutions of a nation as a necessary framework for markets and finance." (emphasis in original)).

33. See generally id. 
circulate and those that are kept; between the public and the private sphere - should be placed in broader frame.

\section{B. TRANSCENDENCE AND THE SACRED}

Another perspective from which to analyze non-market forms of value is through the lens of "political theology," drawing on the work of Carl Schmitt. ${ }^{34}$ According to Schmitt, market relations operate in the shadow of the heterogeneity of the friend/enemy divide, not the homogeneity of market price and exchange. 35 Supposedly, secular notions such as sovereignty are in fact theological in their core structure or source. 36 Legal theorist Paul Kahn, among others, has developed this trajectory in his work on the political culture of the United States. 37

Kahn's project is to discern the ways in which Americans simultaneously live in a liberal world of law and a sacred sovereign order. 38 In Kahn's telling, the sovereign and the sacred dimensions of political order, visible in the notion of a divine king, are relocated to the popular sovereign as popular sovereignty emerges in revolution and is objectified in the Constitution. 39 Where Carpenter found liberal theory problematic in the context of indigenous communities, Kahn, similarly, finds liberal theory grounded in contract, consent, reason, and the practice and metaphor of the market - an incomplete lens through which to understand our political community and its own grounding in sacrifice and sovereignty. 40 The experience of the sacred is paradigmatically found in sacrifice: the act through which the citizen gives themself to the political project. In sacrificial action, upon which the state is founded and preserved, we enter a relation inexplicable to the liberal order since liberalism deems individual life the highest value. From Thomas Hobbes onward, Kahn contends, contract theory cannot explain the moment at which the citizen gives their

34. Carl Schmitt, Political Theology: Four Chapters on the CONCEPT OF SOVEREIGNTY 36 (George Schwab trans., 2005).

35. Id.

36. For different ways of conceiving of Schmitt's use of religion - as analogy and homology, among others, see Banu Bargu, Stasiology: Political Theology and the Figure of the Sacrificial Enemy, in AFTER SECULAR LAW 140, 140 (Winnifred Fallers Sullivan et al. eds., 2011).

37. Paul W. Kahn, Political Theology: Four New Chapters on the Concept of SOVEREIGNTY 38 (2011).

38. Paul W. Kahn, Putting Liberalism in its Place 251 (2004).

39. Id. at 257. Mateo Taussig-Rubbo, Sacrifice and Sovereignty, in StATES OF Violence: WAR, CAPITAL PUNISHMENT, AND LeTting DIE (Austin Sarat \& Jennifer L. Culbert, eds. 2009).

40. Id. at 15-16, 231. 
life for the state. 41 Thus, political violence and the military take on particular significance for Kahn. ${ }^{42}$

To the immanent market, political theology counterpoises the transcendent sovereign and state. Whether concerned with personal property and inalienability, or the transcendence of sovereignty, both approaches can be seen as arising in opposition to, and complementary with, market value. How, then, might we envision a broader picture composed of both market value and non-market value? Rather than recapitulating the dichotomy between the foundational, transcendent or inalienable sites that are fixed and ground a social order - and the value generated through exchange, circulation, and movement - we should treat the dichotomy as a whole, as composed of complementary and interdependent senses of value. Rather than police the boundary, as I understand Radin's effort; or collapse one side into the other, as some economists might attempt by declining to discuss value in favor of individual preference or utility; 43 or treat the sovereign order as distinct, as Kahn does, I am interested in how the opposed forms of value interpenetrate at times and are kept separate at others. ${ }^{4}$ In the divides between medals versus money, and soldier versus contractor, we have a provocative case study.

41. Id. at 63 .

42. See generally id.

43. Modern economics displaces normative questions of value with a focus on individual utility and preference. Value becomes simply the expression of individual preference - hence it is a "subjective" conception of value, and the notion of value as a social, objective fact, as developed, for instance, in John Locke or Karl Marx's "labor theory of value," is left behind. See CARL MENGER, PRINCIPLES OF ECONOMICS 120-21 (1976) ("Value is thus nothing inherent in goods, no property of them, nor an independent thing existing by itself. It is a judgment economizing men make about the importance of the goods at their disposal for the maintenance of their lives and well-being. Hence value does not exist outside the consciousness of men. It is, therefore, also quite erroneous to call a good that has value to economizing individuals a 'value,' or for economists to speak of 'values' as of independent real things, and to objectify value in this way. For the entities that exist objectively are always only particular things or quantities of things, and their value is something fundamentally different from the things themselves; it is a judgment made by economizing individuals about the importance their command of the things has for the maintenance of their lives and well-being. Objectification of the value of goods, which is entirely subjective in nature, has nevertheless contributed very greatly to confusion about the basic principles of our science"). For an insightful discussion and review see DANIEL HAUSMAN, PREFERENCE, VAlue, ChOICE, AND WelFARe 62-65 (2012).

44. See William IAn Miller, Eye For An Eye 199 (2006). Miller maps out a position that insists on the virtual unavoidability ranking, comparison and pricing (contra incommensurability and other objections), while also insisting on how much more nuanced and complex comparing and pricing actually is (contra economists who see a simple task of preference ranking). Id. 


\section{ECONOMIC THEOLOGY}

One recent effort to develop a perspective that encompasses value broadly and sees transcendent political theology and everyday market value as mutually constitutive is found in the work of anthropologist David Graeber. 45 In a retelling of the history of debt, he insists on the importance of seeing credit as historically and analytically prior to money and barter. He argues against Adam Smith, and much of present-day economics, in which the opposite story is told: one in which a natural tendency to truck and barter, along with a division of labor, led to markets, and thence money, and finally coins stamped by the state. 46 This traditional story has the important consequence of making money appear essentially similar to all the other forms of value that have come before, - albeit more convenient and efficient. By contrast, Graeber's story is one in which credit among persons and communities known to each other is the first way in which exchange was effected.

In many small-scale societies, to the extent there is something that looks like money, such currencies - such as beads, shells, feathers, dog or whale teeth, gold, and silver - are often "never used to buy and sell anything at all."47 "Instead," Graeber writes, "they are used to create, maintain, and otherwise reorganize relations between people: to arrange marriages, establish the paternity of children, head off feuds, console mourners at funerals, seek forgiveness in the case of crimes, negotiate treaties, acquire followers - almost anything but trade in yams, shovels, pigs or jewelry." 48 Hart makes a similar point in his discussion of the renowned kula ring of the Trobriand Islands, where ceremonial exchanges of personal ornaments (necklaces and bracelets) link trade partners from different groups and over extended periods of time. 49 These objects are not money, where money is defined as a commodity and as medium of exchange. But they are money in that they are "tokens of interpersonal relations, a sophisticated device for ranking political credit in an unstable environment of trade and war between communities."50 These kinds of money Graeber and Hart call "social currencies," and the economies they appear in "human economies." 51

45. See DAVID GRAEBer, DebT: the FirST 5,000 YeARs 71 (2011).

46. $I d$. at $24-41$.

47. Id. at 130.

48. Id.

49. Hart, supra note 30 , at $647-48$.

50. Id. at 649 .

51. GRAEBer, supra note 45, at 130; see also Chris HANN \& KeItH HART, ECONOMIC ANTHROPOLOGY: HISTORY, ETHNOGRAPHY, CRITIQUE 6 (2011). 
Money as a portable, durable store and measure of value used in exchange for everyday commodities is not the organic outgrowth of local credit structures, or - in the economists' version - an outgrowth of barter. Summarizing a broad sweep of Eurasian history, Graeber argues that money, states, markets, and armies emerged together.52 Where social currencies had local value embedded in credit relations, it was soldiers, persons who traveled outside local credit structures, who created a need for payment in a portable form. 53 To pay them, states collected taxes, which inadvertently engendered markets where subjects would exchange commodities for money, which was whatever the state would accept as taxes. 54

Intriguingly, Graeber urges that:

Money almost always arises first from objects that are used primarily as adornment of the person.... There are exceptions (cattle, for instance), but as a general rule, it's only when governments, and then markets, enter the picture that we begin to see currencies like barley, cheese, tobacco and salt. 55

These two stories - the depiction of social currency as arising through adornment, and the emergence of decontextualized money as a product of war and state formation - nicely confound our current contrast between money and medals and provoke a number of questions. Are decorated soldiers or veterans wearing money in this sense - as social currency? Does this suppose that the military is a "human economy?"

Medals, as discussed in more detail later, are concerned with arranging relations among people. The military does not purport to be concerned with money accumulation as such. Yet the notion of a correspondence between the anthropologist's small-scale, non-capitalist community and our military is perverse, or at least too decontextualized. The latter is embedded in and advances the interests of the preeminent capitalist state, one which through the military and other institutions, especially in the post-war and post-Bretton Woods era - has created and maintained, thus far, a global order of value through its money. Thus, adapting Graeber's stories, soldiers may be wearing primitive money, even while deeply embedded in sustaining money as an abstract, global form of value.

In sum, Radin takes an important step in mapping personal property as distinct from the market; Kahn elaborates the continuing role of the

52. GRAEBER, supra note 45, at 226.

53. Id. at 213.

54. Id.

55. Id. at 145 . 
transcendent and the sacred in grounding a market order; Graeber and Hart urge that we consider the ways in which markets and states mutually constitute one another. Each of these assists in an interpretation of the medal system we find in the military. Probing the fragmentary story of the Purple Heart helps lay out some of the terrain.

\section{WEARING MONEY: THE VALUE OF MILITARY MEDALS}

The Purple Heart website describes Washington's invention as a response to the lack of funds from Congress: "[d]eprived of his usual means of reward [promotion and pay increases], he must have searched for a substitute." ${ }_{6}$ This suggests a relation between money and ribbon as that of a stand-in or a surrogate. But this is an unstable relationship, especially if we wish to find a common point of valuation. We might compare - as did Adam Smith - the lost wages to the value we might assign to the enhanced social standing granted by being honored. ${ }^{57}$ From this perspective, we might worry that the honor seems like a trick or a "bad" deal: calling a loss a sacrifice or awarding a medal may simply serve to avoid giving soldiers more money. 58 Washington's story of honoring with ribbon seems to speak directly to an effort to buy peace and to pay a debt in another currency. In this reading of the Purple Heart story, the cloth comes in lieu of "real" compensation.59 What looked like substitution, perhaps, turns into larceny. 60

This conception is rendered more complex when we ask what the difference is between money compensation and ribbons. Famously, the paper money issued by the Continental Congress had itself radically depreciated in value by the time of Washington's order.61 Thus, rather than a clear distinction between paper money and symbolic ribbon, both are symbolic forms issued by government, and both can be seen as substitutes

56. DEPT. OF CAL. MIL. ORD., supra note 3.

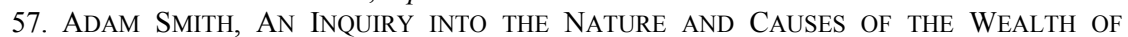
NATIONS 106 (Univ. of Chi. Press, 1993) (1776).

58. Id. ("What a common soldier may lose is obvious enough. Without regarding the danger, however, young volunteers never enlist so readily as at the beginning of a new war; and though they have scarce any chance of preferment, they figure to themselves, in their youthful fancies, a thousand occasions of acquiring honour and distinction which never occur. These romantick [sic] hopes make the whole price of their blood. Their pay is less than that of common labourers, and in actual service their fatigues are much greater.").

59. Raymond, supra note 1.

60. See Carol Rose, Giving, Trading, Thieving and Trusting: How Gifts Become Exchanges, and (More Importantly) Vice Versa, 44 FLA. L. REV. 295, 315-17 (1992).

61. Jerry W. Markham, 1 a Financial History of the United States: From CHRistopher COLUMBUS TO THE ROBBER BARONS (1492-1900), at 68 (2002). 
for "real" value as measured in specie or a commodity. 62 If we want to ask whether the cloth used as adornment could have some money-like value, we should ask the inverse question of whether money could have some nonmonetary value. In fact, radically devalued paper money was used by soldiers on the body in lieu of cloth - as bandages to treat wounds and as clothing. ${ }^{63}$ Unlike Graeber's primitive money, which was worn because it was valuable, wearing Continentals was a sign of just how worthless they had become. Glimmers of this insecurity around the value of money have recently made a comeback in the wake of the financial crisis - due in part to the substantial creation of money the government has engaged in.64 This has reminded many that our money is "fiat" money, and is not, since Nixon, tied to specie. 65 Nonetheless, fiat money has remained valuable and relatively stable thus far, and we do not see soldiers and contractors wearing it as clothing or using it as bandages.

Seeing the medal or cloth as a trick or bad deal is a cynical interpretation, and possibly offensive because it fails to see the medal as a symbol of transcendent loss and heroic action. Even if, in economistic mode, we determine that the medal is a "good" deal in terms of the value of enhanced social standing, this might seem an improper analysis to undertake in that it seeks to find a single point of evaluation. For those committed to the notion that there is a divide between market and honor, such a homogenizing analysis treats money as commensurable with the other ideas of value at play - love for comrades or nation, for instance.

This raises an alternative conception of the relation between money and medals, one opposed to the substitution notion. Drawing on Radin, we might call this conception one of incommensurability, that medals are not a

62. Id. Soldiers were also paid in certificates of indebtedness, "indents," "when there were no funds to pay them." Id.

63. Id. at 68 ("A barbershop in Philadelphia papered its walls with Continental notes"); see also JASON GOODWIN, GREENBACK: THE ALMIGHTY DOLLAR AND THE INVENTION OF AMERICA 72 (2003) ("An old soldier, wounded in the leg, used a bundle of his pay as a bandage, and coined the word 'shinplaster,' which was later used to describe any sort of money that could not be redeemed. A ship's crew discharged in Boston, and paid off in now worthless currency, found a way of making suits out of the paper bills and paraded through the streets. 'For two or three years we constantly saw and were informed of creditors running away from their debtors, and the debtors pursuing them in triumph, and paying them without mercy,' wrote [a contemporary observer].").

64. Ralph Benko, Fiat Money: The Root Cause of Our Financial Disaster, ForBes (Aug. 15,2012 ), http://www forbes.com/sites/ralphbenko/2011/08/15/fiat-money-the-root-cause-of-ourfinancial-disaster/.

65. See Maurer, supra note 30, at 18; JeRry W. MARKhAM, 3 A FinANCIAL HiSTORY OF THE United States: From the Age OF Derivatives inTO THE NeW MillenNiUm (1970-2001), at 38 (2002). 
payment, and that they could never be a substitute for money. 66 But note that the category of personal property does not seem adequate to describe this context, even though it is one that is opposed to market valuation.

The awarding of the medal or ribbon is oftentimes not described as a giving or transfer, but rather as an acknowledgement of that which cannot be compensated. 67 The fact that the item given often has little cash value is not a defect, but rather helps to signal that we are in a different domain of value. 68 The individual is linked to a larger collectivity by the very fact that they have not received fair compensation. It is just this "debt" or imbalance which links the individual to the larger entity, turning an exchange relation into a relation of incorporation. As Graeber writes of primitive money, it "was not originally a way to pay debts of any sort. It's a way of recognizing the existence of debts that cannot possibly be paid." 69 The medals are not beyond market value simply because they are within Radin's "personal" domain; rather, the medal helps mark the transformation of the recipient from an ordinary person into something exceeding their private self. 70 The Medal of Honor Foundation articulates this conception nicely, calling medal recipients a "national treasure."71 But when the imbalance in payment is not understood as an incorporation into a larger whole, it is easily construed as larceny. Indeed, the larceny interpretation cannot be excluded, at least as a latent possibility, because it is a precondition of the incorporation interpretation.

66. See generally Radin, supra note 23. Radin does not use the term "incommensurable" in her Property and Personhood article. I use the term to refer to the claim that there are different kinds of value that are not comparable. Thus, for example, I depict the sense that medals are given to recognize action that cannot be purchased with money as expressing a sense that medals and money are "incommensurable." I do not mean that, in fact or in some analytic sense, they cannot be compared and ranked. In the abstract, it seems equally correct to say that everything can be compared; or that nothing can be compared. Culture, we might say, is the scheme through which a given community navigates between those two logically possible but sociologically impossible positions. William Miller notes the conceptual confusions that abound in this context. MiLLER, supra note 44, at 237 ("Often, what precisely is meant by values and by incommensurability varies from author to author. Some take incommensurability to mean strictly requiring a single scalar metric such as dollars; others argue that the issue is not scalar metrics but whether rational comparisons can be made. Comparisons require only that we be able to declare something greater than, equal to, or less than another thing with respect to some value in some context. Other confusions: some seem to be arguing against the marketability of certain things, like love, babies, art; others are simply against ranking things hierarchically in some kind of esteem regime.").

67. See, e.g., Brief for Medal of Honor Foundation, supra note 13, at 4.

68. See, e.g., Brief for American Legion, supra note 8, at 3 (citing LT. B.G. BuRKETT, STOLEN VALOR: HOW THE VIETNAM GENERATION WAS ROBBED OF ITS HEROES AND HiSTORY (1998)) ("And one of the only things they get is decorations - 62 cents of material, but they're the esteem of the nation bestowed upon you.").

69. GRAEBER, supra note 45, at 131.

70. See generally Radin, supra note 23.

71. Brief for Medal of Honor Foundation, supra note 13, at 3. 
Evoking Schmitt and Kahn, we might say that medals are not just separate from money value, but in fact, the value of the medal grounds the value of money. 72 The recipient of the medal has, in the extreme case, preserved the life of the polity and given their own life in so doing. ${ }^{73}$ The effect of giving oneself for the political project of the nation, and the ways this transforms loss into something else, into sacrifice, is evidenced most starkly in Lincoln's words at Gettysburg, where individual death leads to a "new birth." 74

Washington's medals were to be available to enlisted men, an appropriate republican innovation, the Purple Heart website recounts, since in Europe medals were for aristocrats. 75 In practice, however, there were very few of Washington's awards created, and they do not appear to have become an established social currency embedded in a military or broader social community. ${ }^{76}$ The United States did not begin to create our current system of medals until the early twentieth century 77 - when the country was far removed from an amateur militia or ideologies of Jeffersonian democracy, and was, rather, on the path to overseas imperial prominence, industrial warfare, and a permanent standing army. 78 Since the actual relation between money and medals will always be historically specific and institutionally grounded, we must attempt to sketch out the relevant context for our era.

72. See generally KAHN, supra note 38; SCHMITT, supra note 34.

73. This view is espoused in the American Legion's brief to the Supreme Court, where it quotes from Lt. B.G. Burkett's book on stolen valor: "The Constitution does not guarantee freedom; that's a piece of paper. The only thing that guarantees your rights is the willingness of citizens to stand up against our enemies." Brief for the American Legion, supra note 8, at 3 (citing LT. B.G. BuRKeTt, StOlen VALOR: HOW THE VietNAM GENERATION WAS RobBED OF ITS HEROES AND HISTORY (1998)).

74. Abraham Lincoln, "Gettysburg Address" (Nov. 19, 1863), available at Yale Law School, The Avalon Project, Documents in Law, History and Diplomacy, http://avalon.law.yale.edu/ 19th_century/gettyb.asp.

75. Raymond, supra note 1.

76. David F. Burrelli \& Fenwick Gilroy, Cong. Research SerV., R42704, The PURPLE HEART: BACKGROUND AND ISSUES FOR CONGRESS 2 (2012) ("Records are incomplete and researchers debate how many soldiers received this award, but at least three sergeants from Connecticut are known to have received the award after the American Revolution. However, the Badge of Military Merit fell into disuse shortly after its conception.”).

77. Brent A. Clemmer, Challenges for this Kind of War: Modifying Army Awards for a New Century of Conflict, AY 2011 SCH. OF ADVANCED STUD. 3 (2011) ("The Army organized these tools into a system that was developed and refined over time during the United States' involvement in World War I and World War II. New awards were created since World War II, yet the basic structure into which they fit remains unchanged.").

78. Jonathan Turley, The Military Pocket Republic, 97 Nw. U. L. REv. 1, 14, 31, 34-35 (2002) (discussing the rise of military as a distinct society after Civil War). 


\section{THE MEDAL SYSTEM IN CONTEXT}

It is commonly observed that the United States military is a world apart from the civilian order in many respects, including socially, legally, and economically. 79 The Department of Defense is the largest employer in the world, ${ }^{80}$ although the Chinese Army and Wal-Mart are not far behind. 81 We have a permanent, standing army. It is not, as was largely the case through World War II, a force created for specific conflicts (although there have been seemingly unceasing "small" wars). 82 Since the end of conscription in the early 1970s under President Nixon, with the support of economist Milton Friedman, 83 the military has been a volunteer force. Finally, it increasingly utilizes a large number of private contractors, drawn from many nations. 84 These features of size, permanence, volunteerism, and internationalized outsourcing are the relevant context within which to understand the relation between medals and money.

The military order is simultaneously concerned with everyday matters of production, consumption, and destruction, while also encased in a rich iconography and practice that speaks to notions of transcendence, sacrifice, and a non-material world of valor and honor. The Army Field Manual (Field Manual) tells soldiers that the Army is "drawn together by shared values and experiences, sacrifice, and selfless service to the Nation. All subordinate their own welfare to a higher calling." 85 The mere labor of the

79. Jon Michaels, Beyond Accountability: The Constitutional, Democratic, and Strategic Problems with Privatizing War, 82 WASH. U. L.Q. 1001, 1086 (2004).

80. About the Department of Defense (DOD), U.S. DEP'T OF DEF., http://www.defense.gov/ about/ (last visited Jan. 9, 2013) ("With over 1.4 million men and women on active duty, and 718,000 civilian personnel, we are the nation's largest employer. Another 1.1 million serve in the National Guard and Reserve forces. More than 2 million military retirees and their family members receive benefits.").

81. Daily Mail Reporter, Defense Department, McDonalds and WalMart Top Employers...But China is a Close Second, MAIL ONLINE, http://www.dailymail.co.uk/news/ article-2038401/Defence-Department-McDonalds-Walmart-worlds-biggest-employers-list html (last updated Sept. 17, 2011).

82. See generally MARY DUDZIAK, WAR TIME: AN IDEA, ITS HISTORY, ITS CONSEQUENCES (2012); MaX Boot, The SaVage Wars of Peace: SMall Wars and the Rise of AMERICAN POWER (2003).

83. Brian Doherty, Best of Both Worlds: Milton Friedman Reminisces About His Career as an Economist and His Lifetime "Avocation" as a Spokesman for Freedom, REASON ONLINE (June 1995), http://www reason.com/news/show/29691 html.

84. Katherine E. McCoy, Beyond Civil-Military Relations: Reflections on Civilian Control of a Private, Multinational Workforce, 36 ARMED FORCES \& SOC'Y 671, 676 (2010) ("In fact, despite the fact that most PMCs are based in the United States or United Kingdom, approximately 90 percent of the PMC workforce comes from other countries. Depending on the site, between 60 percent and 65 percent of the workforce is composed of locals (called 'host-country nationals,' or $\mathrm{HCNs}$ ), with the remaining 25 to 30 percent being foreigners from neither the sending nor the receiving countries....").

85. U.S. Dep't of ARmy, Field Manual 1, The Army para. 2.41 (14 June 2005) [hereinafter FM 1]. 
soldier is described as something of a sacrament. While money compensation is offered to its members - along with many other benefits the central narrative of the military is that it is a selfless servant of the American people and the Constitution. The Field Manual tells soldiers how General Washington defused an officers' revolt that sought to force Congress to pay their wages. ${ }^{86}$ It cites this as a foundational example of military self-subordination and service, showing "Washington's selfless leadership and willing subordination [that] instituted the tradition of civilian control of the military - a fundamental tenet of the American military profession." 87 While the armed forces, in some crude measure of power, surely seem able to overpower the civilian order - this submission and sacrifice promises to foreswear such a possibility. 88

Despite the ascension of market-oriented thinking, as evidenced by privatization, even though soldiers are now volunteers, our law and policy does not conceive of the soldier as simply another market actor. Economist Milton Friedman described his role in the abolition of conscription as his "most important achievement." 89 And yet in some respects the victory of the market perspective has not been complete. Even though the benefits of military service to the individual (including health care and education) are openly acknowledged, "sacrifice" and valor remain central to American conceptions of military service. Indeed, some argue that the advent of the all-volunteer force has brought with it a separation from the military and an increased but shallow societal reverence. 90 In public rhetoric at least, the soldier is certainly not described as "mercenary," as Friedman suggested we all are, all the time. 91 And the medal system is one important part of the

86. Id. para. 1-14.

87. Id.

88. See Elaine Scarry, War and the Social Contract: Nuclear Policy, Distribution, and the Right to Bear Arms, 139 U. PA. L. REV. 1257, 1308 (1991).

89. Doherty, supra note 83.

90. ANdrew BaCeVich, The New American Militarism: How Americans ARe SEDUCED BY WAR 28-29 (2005).

91. Long after his participation on the Gates Commission, which paved the way for the end of conscription, Friedman recalled a memorable interchange during the Commission's hearings with General Westmoreland:

In the course of his testimony [against an all volunteer force], he made the statement that he did not want to command an army of mercenaries. I stopped him and said, "General, would you rather command an army of slaves?" He drew himself up and said, "I don't like to hear our patriotic draftees referred to as slaves." I replied, "I don't like to hear our patriotic volunteers referred to as mercenaries." But I went on to say, "If they are mercenaries, then I, sir, am a mercenary professor, and you, sir, are a mercenary general; we are served by mercenary physicians, we use a mercenary lawyer, and we get our meat from a mercenary butcher." That was the last that we heard from the general about mercenaries. 
public conception of the soldier as operating in a domain of value distinct from the market order.

\section{A. THE BUREAUSTOCRACY}

Valor: Heroism performed under combat conditions. Heroism: Extreme courage demonstrated in attaining a noble end.

-ARMY REGULATION 600-8-22, MILITARY AWARDS

Over 210 pages, Army Regulation 600-8-22, Personnel-General, Military Awards, lays out in baroque detail the Army's scheme for awarding medals. ${ }^{2}$ As compared with Washington's short order, it is hard to read the current regulation without seeing the articulation of a comprehensive and effective social currency. It is a currency occasionally linked to money, as when an award also brings with it a pay or pension increase. But it also seems to be a free-standing order of value in a thoroughly hierarchical order of distinctions in which the individual can wear a record of their achievements on their person. The document conjures what we might call - drawing inspiration from Max Weber's ideal types of authority 93 - a bureaucratic-aristocratic world, a bureaustocracy, with numerous and precise heraldic distinctions and complex processes. It is a remarkable effort to capture and recognize the spontaneous, surplus act of valor. Amidst the dense hierarchy, many of the awards seem to preserve a notion of the meaningfulness of individual action.

The award system is one of the three kinds of compensation offered by the Army, including salary paid in money, promotion to higher rank, and awards (this is not to mention the many benefits offered to veterans). ${ }^{94}$ It is important to underscore that the modern military is a "not-for-profit" entity and its soldiers are paid a set wage. 95 There are no longer bounties or prizes through which individual soldiers or the military as a whole share directly in the spoils of war (although pay can be withheld as a punishment). 96 The

David Henderson, The Role of Economists in Ending the Draft, 2 ECON. J. WATCH 2, 370 (2005) (quoting MiLTON FriedMAN \& Rose FriedMAN, TwO LuCKY PEOPLE 380 (1998)).

92. AR 600-8-22, supra note 1.

93. MAX WEBER, 2 ECONOMY AND SOCIETY 668 (1978).

94. Clemmer, supra note 77 , at 10.

95. With respect to the Navy, see Nicholas Parillo, The De-privatization of American Warfare: How the U.S. Government Used, Regulated, and Ultimately Abandoned Privateering in the Nineteenth Century, 19 YALE J.L. \& HUMAN. 1, 14 (2007).

96. See Uniform Code of Military Justice, 10 U.S.C. $\$ 857$ (2006); Bell v. United States, 366 U.S. 393, 401 (1961) ("Preliminarily, it is to be observed that common-law rules governing private contracts have no place in the area of military pay. A soldier's entitlement to pay is dependent upon statutory right.... If a soldier's conduct falls below a specified level he is 
Army explains that the "goal of the total Army awards program" is "to foster mission accomplishment by recognizing excellence of both military and civilian members of the force and motivating them to high levels of performance and service." 97 Pay in money is tied to rank and length of service and is not directly tied to performance. The medals are not to be promised in advance as a precondition of receiving a particular goal; they "will not be used as prizes in contests,"98 and they are not "gifts."99 Awards purport to simultaneously "recognize" and "motivate" 100 and they are not to be given in "exchange."101 These medals are awards, not rewards. As a system of signs, different pieces of metal and cloth arranged in the proper order, the medal communicates precise information about where the wearer has served (service medals for particular campaigns), training and skills (badges), and notable individual conduct (decorations and medals). ${ }^{102}$ It is, as Brent Clemmer writes, a curriculum vitae worn on the uniform, legible to those who know the system. 103

The current elaborate, systematic, and hierarchical system of medals and honors dates back to World War I.104 Despite the intimation that General Washington is a direct ancestor, then, the emergence of the current medal system is of a more recent vintage. In 1917, a congressionally established committee clarified and raised the standards for the Medal of Honor, which at that time was the only award for valor. 105 Almost one thousand of these medals were revoked in cases where the action performed was not up to the new standard; wearing a revoked medal was deemed a

subject to discipline, and his punishment may include the forfeiture of future but not of accrued pay.").

97. AR 600-8-22, supra note 1, para 1-1. This regulation defines a medal as: "[a] term used to includes [sic] the three categories of awards, namely: decorations, Good Conduct Medal, and service medals. [It] also refers to the distinctive physical device made of metal and ribbon, which constitutes the tangible evidence of an award." Id. Sec. II, at 185.

98. Id. at para. 3-1(e) ("No preconditions for an award may be established such as, for example, when Soldiers are informed in advance that attainment of specific goals will result in the automatic award of a given decoration. Military decorations will not be used as prizes in contests.").

99. 18 U.S.C. § 704(a) (2006); see also Kathryn R. Sommerkamp, Commanders' Coins: Worth Their Weight in Gold?, 1 ARMY LAW. 6, 14 (1997).

100. AR 600-8-22, supra note 1, at para. 1-1.

101. 18 U.S.C. $§ 704(a)$.

102. AR 600-8-22, supra note 1.

103. Clemmer, supra note 77, at 2 ("Much as a professor has a Curriculum Vitae and a job applicant a resume on paper, a soldier wears the symbols of success on the uniform. Although the meanings of the multicolored ribbons on a uniform may mean nothing to the visitor, to those who wear the uniform, there is deep significance, tracing a heritage back to the founding of the United States, and even further to the Legions of old.").

104. Id. at $19-20$.

105. $I d$. at 17 (citing John E. StRandberg AND Roger J. Bender, The CALl of DutY: MilitARY AWARDS AND DECORATIONS OF THE UNITED STATES OF AMERICA 17 (1994)). 
misdemeanor.106 When the Medal of Honor was rendered more rare, additional, and lesser, awards were created.107 In 1918, Congress elaborated a graduated system, one that recognized degrees of valor in a "Pyramid of Honor."108 In the Pyramid of Honor, each decoration - the Distinguished Service Cross, the Bronze Star Medal, the Purple Heart, and many others - is hierarchically defined in relation to one another. 109 By the end of World War II, the current system of medals was largely in place. 110

There continue to be changes in the medal system, especially regarding who and what kind of conduct is recognized. For instance, after General MacArthur reintroduced the Purple Heart in 1932, its eligibility requirements were changed by President Kennedy in the 1960s to include civilians so that "advisors" in Vietnam could be recognized. President Reagan again changed the criteria to include government employees killed by terrorist attacks and soldiers undertaking peacekeeping operations (so as to include the Marines killed in Beirut in 1983). In 1997, President Clinton redefined the award yet again so that only military personnel were eligible. 111 Current controversies include whether post-traumatic stress disorder should be recognized as a qualifying injury 112 and whether soldiers murdered in the United States by civilians or by a fellow soldier should be eligible (for instance, the killing of 13 soldiers in Fort Hood by a fellow soldier is currently considered "workplace violence," not an act by the enemy, as required for the Purple Heart). ${ }^{113}$ More broadly, Clemmer argues that the awards system is out of date because it remains fixated on the statecentered conflicts around which the system was developed (i.e., World War I and World War II). It fails to award "non-kinetic" activity, such as "courageous restraint" at the heart of contemporary conflicts and counterinsurgency doctrine. 114

106. Act of June 3, 1916, Pub. L. No. 64-85, § 122, 39 Stat. 166, 214; see also Clemmer, supra note 77, at 18-19; UNITED STATES WAR DEPARTMENT, ANNUAL REPORT OF THE SECRETARY OF WAR 211 (1922).

107. Michael J. Davidson, Bits of Ribbon and Stolen Valor, FED. LAW, (Sept. 2011), at 21.

108. Act of July 9, 1918, ch. 143, 40 Stat. 845, 870-73.

109. Id.

110. Clemmer, supra note 77, at 29.

111. BURRELLI \& GILROY, supra note 76, at 2-3 (citing General Douglas MacArthur, War Department, General Orders No. 3, Feb. 22, 1932).

112. Id. at 8 .

113. Id. at 5 .

114. Clemmer, supra note 77, at 42-43, 29 ("The World Wars continue to influence the Army's corporate identity and form the frame of reference for awards, while new counterinsurgency theory and doctrine demand a different set of rewards. The design of the pyramid of honor and the extent to which it has remained unchanged is one indication of how entrenched this corporate identity is."). 
This system - robust, complex, and requiring significant effort to administer - establishes a world rather like Graeber's primitive money, one in which money is not used for exchange but rather serves to organize relations among people. A person's standing, history, and actions are made visible on the body. The medals intersect with normal money in that they may lead to higher pay and promotion, and yet they are not by the military's own terms a derivative system.

The medals also have two sides, as Hart said of money. On the one hand, they are creations of the state and its formal power to create value. But they are also understood to recognize a value not created by the state. This other side, however, is not the same as Hart's market value. Rather, the most prominent awards envision and invoke a kind of action that comes as if from nowhere - the individual heroic act. They evoke that which cannot be bought, as in the requirement for the Medal of Honor, going "above and beyond the call of duty." 115 Thus, while the other side of the coin, for Hart, points to the market; the other side of the medal points to the excess and surplus act, even to sacrifice. Indeed, medals seem better thought of as anti-money, because they mark the divide between the military order and commercial exchange.

It is not sufficient to simply note the opposition between medals and money, or assert that medals bear some resemblance to social currency. Even if difficult to define in a precise manner, there is an interdependence of medals and money. For the broad reach of our money as a global form of value depends in part upon the military's global presence which, at least according to the military, relies in some part on its medal system for its "mission accomplishment." 116 Put simply, the global reach of value in the form of money should be seen as bound to the social currency we find in the military's medal system.

\section{B. Giving Oneself: The ENListMent CONTRACT}

We must also locate the medal system in the context of the enlistee's relation to the military. The Department of Defense's four-page standard enlistment form contract, Enlistment/Reenlistment Document, Armed Forces of the United States, DD Form 4/1, provides "[m]y enlistment is

115. AR 600-8-22, supra note 1, at para. 3-7. In the regulation's index "above and beyond the call of duty" is further described: "Exercise of a voluntary course of action the omission of which would not justly subject the individual to censure for failure in the performance of duty ..."..." Id. Sec. II, at 183. The Medal of Honor is "presented by the President in the name of the Congress ...." Id at para. 3-7(b). Others are presented within the military and do not go through civilian channels. For descriptions of individual medals see id. at para. 3-17 to 318.

116. AR 600-8-22, supra note 1, para. 1-1. 
more than an employment contract." 117 It is what courts used to call a status contract - like marriage or naturalization - one that changes the legal status of the party.118 Yet it is has an additional feature, because the terms are subject to unilateral modification. ${ }^{119}$ The enlistee agrees to boilerplate language providing that:

$[\mathrm{M}]$ any laws, regulations, and military customs will govern my conduct and require me to do things that civilians do not have to do. The following statements [of law and policy] are not guarantees of any kind. They explain some of the present laws affecting the armed forces but which Congress can change at any time. 120

It is an improbable "contract," by the lights of current contract doctrine, since one party can change the terms as it sees fit "regardless" of the agreement. 121 It also entails what we would describe in the civilian setting as the specific performance of a services contract - usually thought to be an impossibility. 122 Additionally, the soldier cannot send or pay for a substitute (as could be done in the Civil War). ${ }^{123}$ This contract requires a giving of the self, an incorporation, more than a bilateral agreement. Indeed, it is something "more" than an employment contract, and this excess is expressed in various ritual forms such as oath-taking.

Where Radin drew our attention to the link between personhood and inalienability as a way to understand non-market value, we see something rather different at work in this setting. ${ }^{124}$ Carpenter and her colleagues, in their effort to extend Radin's notion of personhood to the collective level, write that what is problematic for indigenous cultural property claims is that

117. U.S. Dep't of Def., Enlistment/Reenlistment Document, DD Form 4/1 ๆ C.9(a) (Aug. 1998) [hereinafter Form DD 4/1].

118. Interestingly, courts now seem inclined to claim that this contract is like any other contract. Compare Qualls v. Rumsfeld, 357 F. Supp. 2d 274, 279-80 (D.D.C. 2005) with In re Grimely, 137 U.S. 147, 151-52 (1890). The latter used the status contract notion, and, as noted in Qualls, describes enlistment contracts as "special because they bring about a change in status, from civilian to soldier, just like marriage contracts change a man's status to husband and the woman's status to wife." Qualls, 357 F. Supp. 2d at 152.

119. Form DD 4/1, supra note 117 , ๆ C.9.

120. Id. ๆ C.9.

121. Id. C.9(b) (in capital letters in original).

122. RestATEMENT (SECOND) OF CONTRACTS § 367 (1979); see also Anthony Kronman, Specific Performance, 45 U. CHI. L. REV. 351, 372-73 (1978); see also, Udi Sagi, Specific Performance of Enlistment Contracts, 205 MIL. L. REV. 150, 151 (2010) (noting that under a straight forward application of contract doctrine, that "by entering into an enlistment contract, the individual takes upon himself the obligations of a personal services contract, which cannot be specifically enforced under normal contract principles").

123. Act of Aug. 10, 1956, ch. 1041, 70 Stat. 19.

124. See generally Radin, supra note 23. 
"the classic view of property law, including its ownership model, is intimately tied to a paradigm of liberal individualism." 125 In the enlistment context, we have a powerful example of how liberal individualism, fundamentally organized around the notion of inalienable self-ownership, does not capture important parts of our legal order. The mere enlisting of the individual soldier is itself a sacrifice of his or her prior self. ${ }^{26}$ The enlistee is transformed, but this happens through an act of self, alienation, namely the giving and pledging of the self through the oath. The enlistee is degraded in being stripped of a prior legal status as civilian but is also elevated in a new status as a "member," as the contract says, of a powerful entity. ${ }^{127}$ The enlistee bears the marks of public power materialized in the uniform. 128

It is from within this context of giving of the self and the oath that we should locate the medal system. Despite the transformation through the oath, the medal system suggests another notion - that the soldier has not given everything. There is still some surplus that is impossible to extract or alienate merely by an order or oath. This surplus is valor, sacrifice, and heroism. The transactional form is quite nuanced because the enlistee gives "more" than the traditional employee, and yet something remains outside the relation, the giving of which the medal system recognizes.

\section{EXPORTING MEDALS TO THE CIVILIAN WORLD AND THE STOLEN VALOR ACT}

The previous section suggested that medals may be seen as a social currency, a "primitive" form of money often worn as adornment. But the difference between social currencies and medals is especially apparent when we leave the military context and examine how medals operate more generally in society. We find many individuals making false claims to have received a medal - claims that, because medals do not emerge from locally monitored credit structures, are able to pass without challenge. First, this section describes some of the ways that medals are used in civilian society, and how Congress has sought to regulate false claims. ${ }^{129}$ Second, this section describes the efforts to explain the medal system to the courts in the context of the challenge to the Stolen Valor Act.130 While medals are

125. Carpenter et al., supra note 28, at 1028.

126. Paul Kahn, SaCred Violence: Torture, Terror, ANd Sovereignty 134 (2008).

127. Form DD 4/1, supra note 117.

128. For an ethnographic description of this process see generally JOHN W. BORNMANN, BECOMING SOlDIERS: ARMY BASIC TRAINING AND THE NEGOTIATION OF IDENTITY (2009).

129. See infra Part IV.A.

130. See infra Part IV.B. 
understood within the military as a form of non-monetary value, in order to defend the medal system it was necessary to show that medals were useful, that they served to advance a government interest. Third, this section describes how this issue came to a head in the litigation leading up to the Supreme Court's decision United States v. Alvarez, as the parties debated whether the medals were incentives or awards, whether they were useful or whether they were valuable as such. 131

\section{A. Medals in the Civilian World}

The value of a medal is transformed as it is taken from the military to the civilian world. Its meaning becomes more diffuse and out of focus as the medal is transported to social contexts where fewer people are aware of the precise meaning of each medal and do not know how to read the "CV," in Clemmer's words. 132 Yet, if the medals lose some of their specificity when presented to an uninitiated audience, their display marks the bearer as having crossed over from one domain to the other - and in this sense they may become even more vibrant sites of social meaning. There are some routinized formats and methods for translating and deploying medals in civilian life: official formats such as Veterans Day parades; or more entrepreneurial and yet still routinized efforts, such as when the decorated veteran runs for political office or attends a protest and makes reference to his or her status.

The setting apart of a domain of special status has attracted impersonators and fakes. It is claimed that there are "staggering amounts of medals fraud." 133 One newspaper investigation found a third of the persons in Who's Who claiming to have received a medal in fact had not.134 The outraged American Legion recounts that these false claimants are "individuals of note and accomplishment: lawyers, physicians, clergymen, CEOs, business executives, company presidents, university professors, career military officers, teachers, policemen, elected officials, even a psychiatrist." 135

Congress has taken a number of steps to define proper use of medals in the civilian world. In 1904, it patented the Medal of Honor - claiming that the "ornamental Design"136 was a new invention.137 In 1923, Congress

131. See infra Part IV.C.

132. Clemmer, supra note 77, at 2.

133. Brief for the American Legion, supra note 8, at 16.

134. Id. (citing John Crewdson, False Courage Claims for Top Military Honors Don't Hold

Up, CHI. TRIB., Oct. 28, 2008, at 1).

135. Id.

136. U.S. Patent Design No. 37,236 (patented Nov. 22, 1904). 
criminalized the unauthorized "wearing, manufacture, or sale" of medals. 138 Under current law, it is also a criminal offense to purchase or barter military decorations or medals "without authorization."139 The limitation on wearing medals makes it a sumptuary law, albeit in a qualified sense since the prohibition has been interpreted to mean "wearing with the intent to deceive." 140 Congress has not created a comprehensive database of medal holders - so it is difficult to ascertain whether a person is lying or not. 141 Medals can be given as gifts, even if they are not awarded as gifts, because the prohibition refers to an "exchange for anything of value."142 Many of the criminal prosecutions policing the boundary of the medal system involve a financial dimension. The cases listed by the Department of Justice's Operation Stolen Valor are mostly of this kind, 143 for example, where a false Medal of Honor holder receives a larger pension. While the domain is incommensurable in its own terms - that is, one cannot buy medals or the status they confer, and they are understood to not be comparable to payment in money - the boundaries are inadequately policed. If, in the military we are correct to see medals as an effective social currency, in the civilian context the matter is far less certain. Consider, for instance, a recent effort to encourage veterans to wear their medals more often, which suggests that usage of the currency in the civilian context is quite limited. The Secretary of Veteran's Affairs urged "[y]ou don't have to put them on only if you're in a parade.... Wear them when you go play golf. Wear them when you go to the store. Let America know that you took that oath and served." 144

137. Brief for American Legion, supra note 8, at 12 (citing H. REP. NO. 67-1484, at 1 (1923)). The design became subject to public use in 1918. Id.

138. Act of Feb. 24, 1923, ch. 110, 42 Stat. 1286, 1286.

139. 18 U.S.C. $§ 704$ (a) (2006).

140. United States v. Perelman, 695 F.3d 866, 871 (9th Cir. 2012). Barton Beebe, in his analysis of how intellectual property law now operates as a sumptuary code, writes that "no free market democracy would countenance such restrictions [that control competitive consumption directly] on consumer sovereignty," but here we have an exception. Barton Beebe, Intellectual Property and the Sumptuary Code, 123 HARV. L. REV. 810, 815 (2010) ("We have thus turned to intellectual property law because it is the one area of law (outside of prohibitions against fraud) that is capable of protecting forms of distinction from imitation and overproduction.").

141. See generally OfFice of Under-SeCretary of DeFENSE, RePort to the SENATE AND House ARmed Services Committees on a Searchable Military Valor DECORATIONS DATABASE (2009).

142. 18 U.S.C. § 704(a).

143. See Northwest Crackdown on Fake Veterans in "Operation Stolen Valor," U.S. ATTN'Y's OFFICE W. DIST. OF WASH. (Sept. 21, 2007), http://www.justice.gov/usao/waw/press /2007/sep/operationstolenvalor html.

144. Leo Shane III, Dust off Medals for Veterans Day, STARS \& STRIPES (Oct. 21, 2006), http://www military.com/features/0,15240,117426,00 html. 
The Stolen Valor Act of 2005 was only the most recent step in an ongoing effort to constitute distinct domain of value and to police its boundaries. It is especially interesting for our discussion because it does not require anything more than a false statement - that is, the offense need not have any monetary or other tangible effect. It asserts the value of the intangible. And yet, it was precisely because of this separation from any tangible harm that the law ran aground.

\section{B. "VAlue Begets Value"}

The criminalization of false speech raised a conundrum in the litigation leading up to Alvarez. In order to justify the prohibition, the government needed to demonstrate it had a compelling, or at least legitimate, interest. It pointed to its own utilitarian need to manage the armed forces and motivate soldiers. In other words, it spoke in the language of modern economics, a language of incentives. ${ }^{145}$ Were medals incentives, perhaps like money? Before the United States District Court for the District of Colorado, the government explained its interest in the medals system: if the value of medals was diluted by false claimants, "soldiers may well lose incentive to risk their lives to earn such awards." 146 Judge Blackburn found this conceptualization "shocking." 147 To suggest "that the battlefield heroism of our servicemen and women is motivated in any way ... by considerations of whether a medal may be awarded simply defies ... comprehension" and is "unintentionally insulting to the profound sacrifices of military personnel the Stolen Valor Act purports to honor."148 It was improper to suggest that valor and heroism could be viewed as forms of conduct that emerge in response to incentives. Indeed, the court noted, "the qualities of character that the medals recognize specifically refute the notion that any such

145. Clemmer cites one popular version, STEVEN D. LEVITT, FREAKONOMICS 13 (2005) ("Incentives are the cornerstone of modern life. And understanding them - or, often, ferreting them out - is the key to solving just about any riddle ...."). Clemmer distinguishes between internal motivations (the desire to do a good job for its own sake, to provide selfless service) and external motivations (a motivation outside the person or the activity). Clemmer, supra note 77, at 8-9. Interestingly, he includes pay, promotion, and awards as "external". Id. at 9. But such an external conception is apparently troublesome to many other observers (such as the Legion of Valor), as discussed in this section. See infra pp. 126-27.

146. United States v. Strandlof, 746 F. Supp. 2d 1183, 1190 (D. Colo. 2010) (quoting Government Response to Amicus Curiae Brief of The Rutherford Institute, United States v. Strandlof, 746 F. Supp. 2d (2010) (No. 09-cr-00497-REB)), rev'd, 667 F.3d 1146 (10th Cir. 2012), abrogated by, 132 S. Ct. 2537 (2012) and vacated, 684 F.3d 962 (10th Cir. 2012), aff'd, 684 F.3d 962 (10th Cir. 2012).

147. Strandlof, 764 F. Supp. 2d at 1190.

148. Id. 
motivation is at play." 149 The Ninth Circuit, in its decision in Alvarez quoted Blackburn's assessment:

Even if we were to make the unfounded assumption that our troops perform their riskiest missions in the hope of receiving the Medal of Honor, there is no evidence - nor any reasonable basis for assuming that some people's false claims to have received the medal has a demotivating impact on our men and women in uniform. 150

The dilemma the government confronted is intriguing: in order to justify the law, it was necessary to point to instrumental policy concerns, but doing so threatened to collide with the ideology of medals as marking off a different kind of action altogether, one that evoked the importance of symbolic meaning and incommensurability.

The problem of how to explain the government's interest emerged in a variety of ways in the amicus briefs submitted to the Supreme Court. Before turning to the Court's opinion, this Article will first contrast three of these briefs. The Legion of Valor asserted that medals are a "governmentissued currency of valor."151 Accordingly, the crime punished under the Act is "analogous to counterfeiting." 152 In this conceptualization, it is not that medals are tied to money - as in the prosecutions of those who cash in on added pension benefits - rather, medals are themselves a "currency."153 This series of metaphors, that medals are a government currency, which the faker counterfeits, which leads to dilution, allowed for an explanation of the harm and hence the government's interest:

[E]very real bill is worth a little less for the existence of a fake. The existence of fakes causes real bills to be examined with some suspicion upon tender. We have all experienced tendering a bill and seeing the cashier mark it with a counterfeit detection pen.

There is a trace of insult there, however small. 154

Recalling Hart's emphasis on the two sides of the coin, state and market, the Legion of Valor's conception of the value of medals is distinctly statist, because the value comes from the government, and the medals are a government issued currency. It is a "fiat" theory of money and value. 155

149. Id.

150. United States v. Alvarez, 617 F.3d 1198, 1217 (9th Cir. 2010), cert. granted, 132 S. Ct. 457 (2011), aff'd, 132 S. Ct. 2537 (2012).

151. Brief for Legion of Valor, supra note 9, at 11.

152. Id.

153. Id.

154. Id.

155. See Hart, supra note 32 and accompanying text. 
As with such theories, it is liable to attack on the grounds that it does not see money as simply a token or symbol of something with real value - be it gold, or, in this case, an individual's valor.

This other side of the coin is expounded upon in an opposing amicus brief submitted by a group of criminal defense lawyers:

The winners of awards such as the Medal of Honor are heroes. The honors that they have earned, based on these historic acts, are not something that can ever be diluted. The idea that the 'currency,' . . can ever be diluted relies on an idea that the honors are part of a zero-sum game. ... [as] if honor and valor is some sort of finite reservoir and that when one person wrongfully 'drinks' out of that reservoir there is less of a supply for those who are truly entitled .... The honor offers an intrinsic recognition of the great heroism and bravery of the recipients. 156

In this opposing viewpoint, the medals are not currency in a deeper sense. 157 They are not stores of value in and of themselves but simply objects that allow an inner fact or truth about the individual to be visible to others. 158 It is as though the hero is per se valuable, like gold or a national treasure. The medal does not create that value - it indexes it. From the perspective of this group of criminal defense lawyers, the government does not have a legitimate interest.

So which of these perspectives - that of the Legion of Valor or that of the criminal defense lawyers - is correct? Hart's point about the two sides of the coin is that the coin's value is at once social and statist. So, too, with the medal. We simultaneously wish to refer to a truth about the individual, and yet seek to use public power to stabilize the system of symbols. The Army regulation discussed earlier touches upon this point in its definition of decorations as "mark[s] of honor denoting heroism or meritorious/ outstanding service/achievement."159 It does not purport to constitute value.

Perhaps the most intriguing effort to explain the government's interest can be found in the amicus brief of The Medal of Honor Foundation. 160 The "purpose behind such awards is not merely to honor brave and heroic deeds, but to inspire emulation." 161 They "inspire" soldiers "to engage the

156. Brief for the National Association of Criminal Defense Lawyers as Amicus Curiae Supporting Respondent at 36, United States v. Alvarez, 132 S. Ct. 2537 (2012) (No. 11-210), 2012 WL 215300 (emphasis in original).

157. $I d$.

158. See id.

159. AR 600-8-22, supra note 1 , Sec. II, at 184 (emphasis added).

160. Brief for the Medal of Honor Foundation, supra note 13, at 9-10.

161. Id. at 9 . 
enemy, and to be ready to act cohesively as a unit despite the danger and chaos they will encounter. It inspires most to carry on while others are falling around them."162 In short, the medal system serves to "inspire heroic acts without thought of receiving a medal." 163 Evidently, what the Medal of Honor Foundation called the Ninth Circuit's "superficial analysis" hit a nerve. 164

Implicit in the court's reasoning was the notion that the only way to understand the need to regulate medals was if they were incentives and this, in turn, implied that soldiers were conscious, calculating, benefit-seeking actors - this was what was "shocking" to the district court. The problem the Medal of Honor Foundation confronted was subtle: how to explain the instrumental importance of the medal system without degrading the heroic and sacrificial action as something triggered by a shallow desire to be given an honor or award. The Legion of Valor sought refuge in the metaphor of currency and dilution, but this argument ran into the accusation that it was too statist. The Medal of Honor's answer was that medals were not only about recognition - they transformed soldiers through "emulation," not conscious award-seeking behavior. 165 Indeed, they acted "without thought of receiving a medal."166 The amici squared the circle of combining instrumental rationales with the excess of sacrifice by asserting, in a striking formulation, that "valor begets valor." 167 Valor is not generated by desire for money or even desire for recognition. Nor is it simply a stategenerated product. It is a self-sustaining cultural value, one that needs some state protection, but is not state-created.

Taken together, the three groups each illustrate a different side of the issue: the value of medals is simultaneously created by the state and by action that is not within its control. The Medal of Honor Foundation's notion that valor begets valor seems to offer the best synthesis since it also understands that at issue is a general social value - not simply a state product or individual transactions and actions. But it was not enough, it turned out, to sustain the Act.

By the time the litigation reached the Supreme Court, the government made clear that it rejected the view that soldiers "rise to the occasion purely

162. Id. at 10.

163. Id. at 6 (emphasis added).

164. Id. at 26 .

165. Id. at 6 .

166. Id.

167. Id. at 33 . 
in hopes of receiving a medal."168 It also argued that simply because awards are not incentives, this need "not detract from the force of the armed services' longstanding view that military awards are a vital means of inspiring higher performance and maintaining the morale necessary for effective unit performance." 169 In other words, the government urged that the awards could be seen as both recognizing valor and as instrumental.

\section{The Alvarez Decision}

The tensions over how to understand the medals system were in full view in the Supreme Court's opinion overturning the Stolen Valor Act. 170 The case dealt with false statements made by Xavier Alvarez, who, when introducing himself as a new member of his local water board in California, said: "I'm a retired marine of 25 years. I retired in the year 2001. Back in 1987, I was awarded the Congressional Medal of Honor. I got wounded many times by the same guy." 171 These were all false statements, made not for any financial gain, but simply, Justice Kennedy thought, as "a pathetic attempt to gain respect that eluded him." 172

A majority voted to strike down the law. But if we isolate the question of what kind of value is at issue, the matter is more complicated. In his plurality opinion, Justice Kennedy, joined by Chief Justice Roberts, and Justices Ginsberg, and Sotomayor, contrasted the law to other prohibitions on lying since here there was no "legally cognizable harm."173 While perjury undercuts the judicial system and falsely representing oneself as an official undermines government, the Act "targets falsity and nothing more." 174 The lack of a link to monetary or some other tangible gain was deeply problematic: "a ban on speech, absent any evidence that the speech was used to gain a material advantage ... would give government a broad censorial power." 175 It is as though the government has been too successful in creating an incommensurable domain of value - merely claiming to be a member was itself sufficiently attractive, without any other tangible gain. In any case, as the offense was not linked to a "material advantage," the law

168. Brief for the United States 39 n.8, United States v. Alvarez, 132 S. Ct. 2537 (2012) (No. 11-210), 2011 WL 6019906.

169. Id.

170. United States v. Alvarez, 132 S. Ct. 2537 (2012).

171. Id. at 2542 (quoting United States v. Alvarez, 617 F.3d 1198, 1201-02 (9th Cir. 2010)).

172. Id.

173. Id. at 2545 (Kennedy, J., plurality opinion).

174. Id.

175. Id. at 2548 . 
fell outside the small number of permissible content-based restrictions on speech and was thus subject to fatal "exacting scrutiny."176

Justice Kennedy recognized the government's "compelling interests" in the medal system since "public recognition of valor and noble sacrifice ... reinforces the pride and national resolve that the military relies upon to fulfill its mission."177 But he was skeptical that there was a "direct causal link" between the prohibition and the interest protected. ${ }^{178}$ It was not enough to claim, as did the government, that it was "common sense" that liars "dilute the value and meaning of military awards." 179 While a link to monetary gain would have assuaged Kennedy's concerns in his analysis of why lying was prohibited, he did not see the medal system as another currency, another artificially created symbolic order of scarcity, in which it would be axiomatic or "common sense" that an increase in supply dilutes relative value. Instead, Kennedy tended toward a conception of the medals as recognizing heroism, not constituting a form of value. Approvingly quoting the Veterans of Foreign Wars amicus brief, Kennedy declared that the "general proposition is sound" that "there is nothing that charlatans such as Xavier Alvarez can do to stain [the Medal winners'] honor."'180 That is, the value recognized is inherent in the Act. Moreover, there was a less burdensome way to advance the government's interest, namely through public refutation and shaming of liars, as happened to Alvarez, not criminal prosecution. Rather than seeing a problem of counterfeiting, the problem was speech and the solution was "counter-speech." 181 He did, however, turn to the favored commercial metaphor in the free speech context: the "best test of truth is the power of the thought to get itself accepted in the competition of the market."182 The public outrage directed at Alvarez's lies "fully vindicated" the government and the genuine medal holder's interests. ${ }^{183}$ In a flourish, Justice Kennedy noted that the "American people do not need the assistance of a government prosecution to express their high regard for the special place military heroes hold in our tradition.... Truth

176. Id.

177. $I d$.

178. $I d$. at 2549 .

179. Id. (quoting Brief for the United States 54, United States v. Alvarez, 132 S. Ct. 2537 (2012) (No. 11-210), 2011 WL 6019906).

180. Id. (quoting Brief for the United States 54, United States v. Alvarez, 132 S. Ct. 2537 (2012) (No. 11-210), 2011 WL 6019906).

181. Id.

182. Id. at 2550 (citations omitted).

183. Id. 
needs neither a handcuffs nor a badge for its vindication."184 However, a currency very well might.

Justice Kennedy underscored his desire to move away from contemplating intangibles by indicating that the Stolen Valor Act would be less vulnerable if linked to "fraud or [undertaking to] secure moneys or other valuable consideration." 185 Such a law would return us to more easily grasped notions of value as connected to money or some other tangible valuation, relieving us of the quandary of just what it means to "steal" valor.

Even though the Act was overturned, there were five Justices who accepted the claim that liars presumably harm the medal system. Justice Breyer, concurring (with Justice Kagan), wrote that to "permit those who have not earned those honors to claim otherwise dilutes the value of the awards," 186 and he did not question what Justice Kennedy called the "causal connection" between the prohibition and the government's interest. ${ }^{187}$ In dissent, Justice Alito (joined by Justices Scalia and Thomas) framed the "intangible" harm at issue through monetary and trademark metaphors. Unlike Justice Kennedy, for whom the lies were about "falsity and nothing more," the dissent argued that lies "debase the distinctive honor of military awards."188 Like trademark infringement, "the proliferation of false claims about military awards blurs the signal given out by the actual awards by making them seem more common than they really are, and this diluting effect harms the military by hampering its efforts to foster morale and esprit de corps."189 Justice Kennedy's solution, more speech in a "market" of ideas, would not preserve the value of the medals but simply make matters more confused. In sum, this 'majority,' of five concurring and dissenting Justices, was willing to assume that the value to be protected was in part government created, that it was presumably undercut by others pretending to have received that value, and that harm to that form of value need not be translated into a monetary or tangible form in order to garner recognition. 190

184. Id.

185. Id. at 2547. This modification has been also proposed by Congressmen Heck (R-Nev). H.R. 1775, 112th Cong. § 2(a) (2011) (amending the law to require an intent to "obtain anything of value"), available at http:// heck.house.gov/sites/heck house.gov/files/Stolen\% 20Valor\% 20 Bill.pdf.

186. Alvarez, 132 S. Ct. at 2555 (Breyer, J., concurring).

187. Id. at 2555-56.

188. Id. at 2559 (Alito, J., dissenting).

189. Id.

190. Id. at 2552 (Breyer, J., concurring). Breyer applied an "intermediate scrutiny" test one in between the usually fatal strict scrutiny that Kennedy applied and the usually permissive rational basis test. Breyer found that the government's objective could be met in a less 


\section{PRIVATE CONTRACTORS: FROM MEDALS TO MONEY}

This final section briefly examines the implications of the government's reliance on private military and security contractors in its wars in Iraq and Afghanistan in light of our discussion of money and medals. How are we to understand those laborers of war, private military contractors, who are not eligible for most medals? 191

The privatization and outsourcing of government functions has been investigated from a number of perspectives. We can frame the shift to contractors as a policy move away from notions of incommensurability, sacrifice, and "primitive" money, and towards the money economy. 192 The rise of private contractors marks a new relation between the military and a global labor market. Some contractors are highly skilled former soldiers and United States citizens. But the bulk are local and third country nationals performing manual jobs, often socially segregated from the soldiers they service, and often recruited by middle-men.193 This privatization and internationalization is relevant because contractors are typically not eligible for medals - even though they have faced higher fatalities than soldiers. 194 They are not eligible for burial at Arlington National Cemetery, and they are generally excluded from the robust traditions through which soldier sacrifice is honored and recognized. 195 Thus, the turn to contractors raises questions about the changing place of sacrifice in military operations and in our political culture more broadly. 196

Nonetheless, the government has deemed that contractors are eligible for public honor as civilians, through awards such as the Defense of Freedom Medal.197 This is described on an official website as the "civilian

burdensome manner, and thus the law created a "disproportionate constitutional harm." Id. at 2540.

191. See AR 600-8-22, supra note 1, 53-54 tbl. 3-4. The regulation lists which medals may be given to U.S. or foreign "civilians." Id.; see also U.S. DEP'T OF THE ARMY, REG. 672-20, INCENTIVE AWARDS, 4 tbl. 2-1 (29 Jan. 1999).

192. See supra notes 66-69 and accompanying text.

193. See Am. Civil Liberties Union \& YALE LAw SCh. Lowenstein Clinic, Victims of COMPLACENCY: THE ONGOING TRAFFICKING AND ABUSE OF THIRD COUNTRY NATIONALS BY U.S. GOVERNMENT CONTRACTORS 19 (2012); see also McCoy, supra note 84, at 676.

194. Miller, supra note 22; Schooner \& Swan, supra note 22, at 13.

195. 32 C.F.R. § 553.15 (2009); see also Taussig-Rubbo, supra note 29, at 105; see also Schooner \& Swan, supra note 22, at 13.

196. Taussig-Rubbo, supra note 29, at 156 (this section draws on that discussion).

197. Defense of Freedom Medal Unveiled, U.S. DEP'T OF DEF. (Sept. 27, 2001), http://www.defense.gov/releases/release.aspx?releaseid=3068; see also AR 600-8-22, supra note 1, at para. 2-8(1) ("The Defense of Freedom Medal, established on 4 October 2001, is the civilian equivalent to the Purple Heart awarded to U.S. military personnel"); see also Jim Garamone, Intelligence Agency Presents Defense of Freedom Medals, AM. FORCES INFO. SERV. (Oct. 19, 2001), osd.dtic mil/news/Oct2001/n10192001_200110192 html ("The medal commemorates their valor and sacrifice.”). 
equivalent" of a Purple Heart, as both require the recipient to have been injured or killed. 198 The deaths may be called "sacrifices" and recognized as deaths in the name of the nation, 199 but the ceremonies where those awards are given are often private events and exclude the media. 200 It is not only United States citizen contractors who are dying and being recognized for their service. A United States Embassy representative, when awarding the Defense of Freedom medal in Fiji, explained to the Fiji Times that "the ceremony was to honour the five men who bravely laid down their lives as part of an international effort to fight terrorism and create freedom."201 Furthermore, some contractor companies have developed their own medals. The company formerly known as Blackwater, for instance, gave out its Worldwide Defense of Liberty Medal to injured contractors at a private event.202 Thus, while the shift to contactors is a shift out of the military's medal system, there are some signs of a new medal system emerging. There is an attempt to institutionalize both the sacrifice and a non-monetary notion of value of service - but in a manner that protects or excludes the public.

In sum, we can characterize the turn to contractors as a turn away from the military's medal system. At the same time, there are some indications that contractor companies and the government are improvising and developing an alternate medal system. What are the potential implications of the shift out of the traditional medal system? One factor concerns

198. U.S. DEP'T OF DEF., supra note 197.

199. T. Christian Miller, War Contractors Receive Defense of Freedom Medal for Injuries, But Attract Little Notice, ProPuBlicA (Feb. 18, 2010), http://defensebaseactcomp. wordpress.com/2010/02/18/war-contractors-receive-defense-of-freedom-medal-for-injuries-butattract-little-notice.

200. T. Christian Miller, The Battle Scars of a Private War, L.A. TIMES, Feb. 12, 2007, at A1. The Los Angeles Times described one ceremony in which:

Executives in dark blue suits shifted uncomfortably as an Army major general in battle fatigues awarded posthumous Defense of Freedom medals to the families' loved ones, all contractors killed while working in Iraq. But this was no public recognition of sacrifice. The event was held in secret, with guards to keep out the media. The Army even refused to release the names of those it was honoring. The nation's gratitude was delivered behind closed doors.

Id.

201. Monica Singh, Local War Casualties Get Medals, FiJ TIMES OnLine (Aug. 15, 2008), http://www fijitimes.com/story.aspx?id=97870.

202. The Blackwater name was changed to Xe, and the company is now known as Academi. See ACADEMI, http://academi.com/pages/about-us/introduction (last visited Jan. 6, 2013) ("Our name comes from the Greek akademia, an institution founded by Plato and rooted in higher wisdom and skill, producing both thinkers and warriors alike. ACADEMI is that institution today."); see also Defense Watch, DEFENSE DAILY (June 23, 2008), 2008 WLNR 13239185 ("Since it wasn't a public event, the company did not release the names of those honored to the media." President of Blackwater, Eric Prince "presented 'The Blackwater Worldwide Defense of Liberty Medal' to each contractor. 'I thank each and every one of you for your many sacrifices and for your distinguished, selfless service,' Prince said."). 
democratic accountability: if the awarding of medals serves as a governmental and societal reckoning of the costs of war, then, not paying in that currency will presumably avoid awareness of that cost. Another factor concerns equity: while contractors may oftentimes be undertaking the more banal and less dramatic work of war, presumably there are instances in which, were they soldiers, they would be eligible for an award. In such an instance, the award system can seem arbitrary, based on ex ante status and not on individual conduct. This restates the question of the value of medals already discussed: do they create value or do they simply recognize what is already there? The question of equity also provokes a different reaction: if it is a valid assumption that the contractor is motivated primarily by money, not sacrifice and service, it may be entirely appropriate to exclude them from these other forms of compensation that are offered to the soldier.

The rise of the private contractor puts the Stolen Valor Act in a different light. We have a class of persons who may have some plausible claim to the recognition bestowed by medals - but who are per se excluded from the military medals system in general. Through a policy of not recognizing contractors' eligibility for most medals, is their "valor" being stolen as well? If the concern with the false claimant is that they dilute the meaning of medals, here the concern is that the value may be artificially inflated by excluding the large number of third-world workers who may also act heroically. And how do the efforts to create ersatz medals, such as Blackwater's, compare to the conduct the Stolen Valor Act seeks to punish? Are these an effort to steal valor as well; or are they appropriate privatesector solutions to address an inequitable defect in public policy?

And yet there seem to be great dangers in allowing contractors to receive both money and the same medals and public honor awarded within the military. Given our analysis of the important role of the medals within the military, opening up the Pyramid of Honor to contractors would seem to risk confounding and undermining the medal currency and its place within the military world. To put the concern bluntly, while the government explicitly bans the imposter, we may wonder whether it has itself created a class of imposters through its outsourcing policy; or, more sympathetically to the contractors, whether Congress has improperly excluded a class of labor from proper recognition.

The most obvious link between money and medals is one not mentioned yet: that privatization or outsourcing saves money. While this is an oft-repeated claim, what is striking about the military outsourcing over the past decade is the lack of effort expended in collecting even the most rudimentary figures that would enable officials to test the claim of lower 
cost, such as the number of contractors engaged or the total cost.203 Due to a particularity of the military budgeting process, contractors are often hired through contingency funds and thus are often perceived, by senior officials in the military, as "free." 204 But what is incontrovertible is that privatization has proved efficient in terms of moving much military labor out of the heavily sacramental category of soldier - eligible for medals, for recognition for national sacrifice, and so forth - and into the less august category of contractor. To pay in money is to assert that the debt can be settled, and thus permits the government to avoid the complexities of the medals as a social currency.

To see the medal as the socially meaningful token that marks social interconnectedness and money as impersonal and lacking in social meaning would be, however, to forget Hart's image of the two sides of the coin. The shift to contractors and paying in money should not be seen as a shift to the "market" in any simple sense. Both money and medals are, in part, statist undertakings. They differ, however, in how they display their sociability. Money presents itself as abstract and impersonal, even while created by the sovereign. Medals, especially those for valor and suffering, do not claim that the relation between the giver and recipient is thereby concluded.

\section{CONCLUSION}

This Article has examined multiple intersections between, and definitions of, medals and money. In the discussion of George Washington's Purple Heart, it seemed that giving medals was a way to compensate for not giving money. Drawing on Radin and a notion of incommensurability, medals articulated an understanding that some types of action could not be paid for in money. But the Article did not simply

203. See Comm'n on Wartime Contracting in IraQ \& Afg., at What Cost? CONTINGENCY CONTRACTING IN IRAQ AND AFGHANISTAN, INTERIM REPORT16-17 (2009).

204. See COMm'N ON WARTime Contracting, supra note 20, at 22. The Commission report recounts that:

For many senior officials, contractors appear to be a "free" source of labor with no direct impact on their budgets. Funded out of what they perceive to be unconstrained overseas contingency-operation budgets, many senior officials pay scant attention to articulating specific support requirements, negotiating contract terms, and managing contractor performance. A general officer who briefed the Commission during its visit to Kuwait in February 2010 said that if there is no budget restriction and all contractsupport requirements are met, then commanders have no incentive to consider costs. Despite the critical nature of contingency acquisition, this relatively lax approach stands in stark contrast to the way DoD manages its military personnel. Although some improvements have been made, agency officials still have little incentive to consider costs and therefore may choose to minimize performance risk by consuming and paying more than is reasonable or necessary.

Id. 
confound the divide between medals and money by asking whether medals could be seen as money, or whether they were truly different kinds of value.

It also asked whether medals could be seen as a social currency as described by anthropologists, a form of money often worn as adornment. While appealing, this asserted parallel between the medal system and a social currency has a number of caveats in that the medal system does not operate through individuals' local knowledge of credit distributions and is created (or recognized) by the state. The value of social currencies was, as Graeber contended, typically local. ${ }^{205}$ And it emerged in contexts where there is no state. In other words, it is not surprising that a social currency, such as the medal system in a mass society, will encounter the problem of fraud and counterfeiting, since the value does not emerge out of local and individually tracked credit relations. Indeed, what our examination has encountered again and again was that the medal is a fascinating combination of "primitive" money and impersonal, abstract, and statecreated value. It is, we might say, itself a fake kind of social currency fake because it is created by a centralized authority. And yet it is not only a state creation for it purports to recognize valor, heroism and sacrifice, and in this dimension is genuinely a social currency that allows a persons' value to be visible through adornment.

In Graeber's story, states, armies and abstract, decontextualized forms of money emerged together. Thus, to find a social currency occupying a central place in the military is noteworthy. The truly fascinating issue is the interdependence between the state's two currencies: its actual money and its medal system. The key question is whether the state needs its medal currency. We can depict our current order as one composed of both a universal money form that has penetrated more social orders than ever before with a single measure and store of value, but which also relies on a strange form of social currency.

The issue of what sort of value the state could create, and what steps it could take to protect that value, were at the heart of the Supreme Court's decision in Alvarez. Justice Kennedy did not see the value of the social status that the medal system created as one presumptively harmed by false claims, and he indicated that linking the offense to some material loss could preserve the law. A loss of money, even though simply another state symbol, was tangible. A loss in the valor system consisting of dilution was intangible. Justice Kennedy articulated a non-statist, intrinsic, understanding of the value of medals. By this view, the valor of the true hero cannot be stained by the false claimant. The Supreme Court's decision

205. See GRAEBER, supra note 45, at 213. 
removes one tool for policing the boundaries of military honor; and yet, the rest of the statute restricting the manufacture, wearing, and sale of medals remains in force, as does the exclusion of contractors from the medal system.

This Article began by noting the repeated invocation, in the context of the debate around the Stolen Valor Act, of the story of George Washington and the creation of the Purple Heart. Rather than situating ourselves as within that tradition, perhaps our order is better seen as an inversion of Washington's story. Washington "paid" in valor rather than money because the Congress was out of money. Now, the United States increasingly pays in money rather than valor. This may be a concern if the medal currency serves a valuable role in enhancing the accountability of the government and military to the population at large by requiring officials to acknowledge publicly the human impact of war-making. On the other hand, this recognition could also serve to disempower the public if it positions them as grateful recipients of the soldier's beneficence. If paying in medals may mean that the pay offered the soldier was not enough - that pay is never enough - then the medal signifies an ongoing obligation. This may be appropriate, but it is also troubling. That, surely, is an attraction of the contractor - that accounts can be settled.

Is the end point, then, a rather familiar story: that yet another domain of life succumbs to the ethos of the market, and commensurability as measured in money? Things are probably not so simple, and such a conclusion would ignore the continued importance of the medal system in the military. More plausibly, the lesson to take from our examination of the multitude of conceptions of value is that our obligations to one another are not contained in one form of currency and credit, be it money or medals. 